\title{
PEMANFAATAN SITUS KARANGKAMULYAN \\ UNTUK KEPENTINGAN PENDIDIKAN DALAM PEMBELAJARAN SEJARAH
}

\author{
The Utilization Sites of Karangkamulyan for Education Interest \\ in Learning History
}

\author{
Yeni Wijayanti \\ Universitas Galuh Ciamis \\ Jalan R.E. Martadinata Nomor 150 Ciamis \\ E-mail: yeniunigal@gmail.com
}

Naskah diterima 11 Oktober 2016 — Revisi terakhir 6 Juni 2017

Disetujui terbit 7 Juni 2017 - Diterbitkan secara online 22 Juni 2017

\begin{abstract}
The Karangkamulyan site is an archaeological site of megalithic, Hindu Buddhism and Islam. This site was developed as one of the attractions in Ciamis District. However, the utilization as a learning resource in history learning is lacking. The method of research is descriptive qualitative method. The findings showed that visitors who came to Karangkamulyan Site were dominated by the general public with the objectives of nature tourism, while the problems found from the school were there were no permission from the principle, limited hours of study, the additional cost to the location, not distributed publications about Karangkamulyan Site. The conclusion of this paper is that this site can actually serve as an effective historical learning resource considering its location close to the schools. Karangkamulyan site can be utilized by using the method of learning field trip / excursion.
\end{abstract}

Keywords: utilization, Karangkamulyan Site, education, learning history

\begin{abstract}
Abstrak
Situs Karangkamulyan merupakan situs tinggalan arkeologis megalitikum, HinduBuddha, dan Islam. Situs ini dikembangkan sebagai salah satu objek wisata di Kabupaten Ciamis. Namun, pemanfaatannya sebagai sumber belajar dalam pembelajaran sejarah masih kurang. Metode yang digunakan adalah metode deskriptif kualitatif. Temuan yang didapatkan menunjukkan bahwa pengunjung yang datang ke Situs Karangkamulyan didominasi oleh masyarakat umum dengan tujuan wisata alam, sedangkan masalah yang ditemukan dari pihak sekolah adalah tidak adanya izin dari kepala sekolah, jam pelajaran yang terbatas, perlu biaya tambahan untuk ke lokasi, dan tidak terdistribusikannya publikasi tentang Situs Karangkamulyan. Simpulan tulisan ini adalah bahwa situs ini sebenarnya dapat dijadikan sebagai sumber pembelajaran sejarah yang efektif mengingat lokasinya dekat dengan sekolah-sekolah. Situs Karangkamulyan dapat dimanfaatkan dengan menggunakan metode pembelajaran karyawisata/ekskursi/fieldtrip.
\end{abstract}

Kata kunci: pemanfaatan, Situs Karangkamulyan, pendidikan, pembelajaran sejarah 


\section{PENDAHULUAN}

Karangkamulyan merupakan suatu situs yang terletak di Desa Karangkamulyan, Cijeungjing, Ciamis, di tepi pertemuan dua sungai, yaitu $\mathrm{Ci}$ Tanduy (di selatan situs) dan Ci Muntur (di utara situs). Lahan situs luasnya 25,5 hektar, ditumbuhi pohon-pohon besar yang lebat. Situs tersebut dikenal sebagai salah satu lokasi pariwisata budaya Ciamis (Munandar, 2010, hal. 79). Masyarakat setempat menghubungkan Karangkamulyan dengan cerita rakyat Ciung Wanara, putra Ratu Galuh Sanghyang Cipta Permanadikusuma. Menurut legenda Ciung Wanara pada waktu bayi dihanyutkan yang disertai sebutir telur ayam yang kemudian menetas menjadi ayam jantan. Ayam tersebut kemudian menang melawan ayam Hariang Banga. Tempat berlangsungnya sabung ayam tersebut dinamakan Panyabungan Hayam (Munandar, 2010, hal. 79; Saptono, 2002; Haris \& Budiana D, 2013).

Situs Karangkamulyan merupakan salah satu tempat yang tinggalan arkeologisnya dihubungkan dengan Kerajaan Galuh. Situs Karangkamulyan merupakan situs yang berkarakter tempat suci, berlatarkan perpaduan antara agama Hindu dan kepercayaan asli. Di sekitar kompleks bangunan juga ditemui adanya indikator permukiman (Saptono, 1999).

Sampai saat ini, Situs Karangkamulyan sebagai objek wisata budaya merupakan situs yang paling ramai pengunjungnya apabila dibandingkan dengan situssitus lain yang berada di Ciamis, seperti Astana Gede Kawali dan Jambansari. Hal ini disebabkan pengelolaan yang baik, penelitian, publikasi, dan lokasi yang mudah dijangkau (berada di jalan utama provinsi). Pengelolaan Situs Karangkamulyan berada di bawah Balai Pelestarian Cagar Budaya Banten.

Beberapa pihak telah melakukan penelitian dan memublikasikan situs Karangkamulyan sehingga Situs Karangkamulyan semakin dikenal. Situs Karangkamulyan berkembang menjadi objek wisata ziarah, religi, sejarah, dan objek penelitian. Namun, situs tersebut belum dimanfaatkan sebagai objek wisata pendidikan secara maksimal. Berkaitan dengan hal itu, terdapat permasalahan yang akan diungkap, yaitu bagaimana situs Karangkamulyan dimanfaatkan sebagai sumber pembelajaran sejarah.

Objek wisata pendidikan adalah objek wisata sebagai sumber belajar siswa atau peserta didik. Pemanfaatan Situs Karangkamulyan dikaitkan dengan pembelajaran sejarah, baik secara langsung maupun tidak langsung.

Dalam pembelajaran sejarah Situs Karangkamulyan dapat dijadikan sebagai sumber sejarah. Untuk memanfaatkan Situs Karangkamulyan sebagai objek wisata pendidikan, banyak metode yang dapat digunakan, di antaranya dengan model pembelajaran Contextual Teaching and Learning (CTL). Pemanfaatan Situs Karangkamulyan sangat tepat apabila digunakan dalam pembelajaran sejarah sekarang yang menggunakan pendekatan saintifik.

Alasan Situs Karangkamulyan dijadikan sebagai objek wisata adalah yang pertama karena keterkaitan dengan sejarah Jawa Barat pada masa lalu, yaitu Kerajaan Galuh dan Kerajaan Sunda. Alasan kedua adalah bahwa tinggalan arkeologis yang 
ada di Situs Karangkamulyan terkait dengan materi pembelajaran sejarah, terutama sejarah kerajaan masa HinduBuddha.

Berdasarkan permasalahan tersebut, metode yang dipilih adalah metode kualitatif deskriptif. Tulisan deskriptif dirancang untuk memperoleh informasi tentang status gejala saat penelitian dilakukan. Tujuan penulisan ini adalah untuk melukiskan variabel atau kondisi "apa yang ada" dalam suatu situasi (Furchan, 2011, hal. 447).

Menurut Undang-Undang No. 10 Tahun 2011 Pasal 1, Situs Cagar Budaya didefinisikan sebagai lokasi yang berada di darat dan/atau di air yang mengandung Benda Cagar Budaya, Bangunan Cagar Budaya, dan/atau Struktur Cagar Budaya sebagai hasil kegiatan manusia atau bukti kejadian pada masa lalu.

Dalam konteks arkeologi, situs diartikan sebagai suatu tempat yang terdapat di dalamnya artefak, fitur, dan/ atau ekofak. Maka, di dalam suatu tempat tersebut dapat ditemukan peninggalan satu, dua data arkeologi, dan/atau ketiganya (Sharer \& Ashmore, 2003, hal. 122).

Pembelajaran sejarah di sekolah bertujuan agar siswa memperoleh kemampuan berpikir historis dan memahami sejarah. Melalui pengajaran sejarah, siswa mampu mengembangkan kompetensi untuk berpikir secara kronologis dan memiliki pengetahuan tentang masa lampau yang dapat digunakan untuk memahami dan menjelaskan proses perkembangan dan perubahan masyarakat serta keragaman sosial budaya dalam rangka menemukan dan menumbuhkan jati diri bangsa di tengah-tengah kehidupan masyarakat dunia. Pengajaran sejarah juga bertujuan agar siswa menyadari adanya keragaman pengalaman hidup pada setiap masyarakat dunia. Pengajaran sejarah juga bertujuan agar siswa menyadari adanya keragaman pengalaman hidup pada setiap masyarakat dan adanya cara pandang yang berbeda dan tujuan lainnya (Agung \& Wahyuni, 2013, hal. 56).

Selain itu, pengajaran sejarah juga bertujuan memperkenalkan kepada anak, masa lampau dan masa sekarang mereka serta lingkungan geografis dan lingkungan sosial mereka. Sasarannya adalah (1) memberikan pemahaman tentang tahaptahap perkembangan masyarakat, (2) menumbuhkan penghargaan terhadap komponen budaya, (3) menumbuhkan pemahaman kritis tentang masa lalu sehingga para siswa dapat terbebas dari prasangka yang irasional dan fanatik, (4) mengembangkan penghargaan terhadap budaya, kekayaan dan keberagaman serta proses perkembangan yang dilaluinya, (5) mengembangkan kemampuan untuk mengkaji masalah-masalah kontemporer dalam perspektif sejarah, (6) memajukan studi tentang sejarah perkembangan peradaban manusa secara keseluruhnya, (7) mengembangkan pemahaman tentang proses peradaban sehingga pemahaman siswa tentang proses perubahan yang terjadi dewasa ini, (8) dan mengembangkan kesadaran tentang pentingnya pemeliharaan peninggalan sejarah dan partisipasi aktif di dalamnya (Kochhar, 2008, hal. 30).

Peninggalan arkeologi sebagai kebudayaan materi yang diciptakan manusia kapan dan di mana pun pada hakikatnya merupakan representasi yang paling dapat dipercaya yang dapat diperoleh peneliti tentang nilai dan makna yang ada dalam masyarakat. 


\section{HASIL DAN PEMBAHASAN}

Situs Karangkamulyan merupakan salah satu situs yang dimiliki oleh Kabupaten Ciamis yang mempunyai hubungan dengan sejarah Kerajaan Galuh. Perlu diketahui bahwa peninggalan Kerajaan Galuh di Ciamis yang berupa tinggalan arkeologis, antara lain Situs Candi Ronggeng di Pamarican, Situs Astana Gede di Kawali, Situs Karangkamulyan di Karangkamulyan, Situs Gunung Padang di Cikoneng, Situs Gunung Susuru di Kertabumi, Situs Patilasan Sanghyang Cipta Permana Prabu Digaluh di Cimaragas, dan Situs Nagara Pageuh di Panawangan (Lubis, 2013, hal. 88 - 131).

Di Situs Karangkamulyan terdapat sembilan peninggalan arkeologis yang tersebar, yaitu (1) Batu Pangcalikan, (2) Panyabungan Hayam, (3) Sanghyang Bedil, (4), Lambang Peribadatan, (5) Cikahuripan, (6) Panyandaan, (7) Pamangkonan, (8) Makam Adipati Panaekan, dan (9) tumpukan batu Sri Begawat Pohaci. Batu Pangcalikan terletak di atas lahan seluas $25 \mathrm{~m}^{2}$ yang dibatasi pagar batu berukuran tinggi 60 $\mathrm{cm}$ dan tebal $80 \mathrm{~cm}$. Batu Pamangkonan berupa bangunan berbentuk empat persegi yang dibatasi oleh pagar atau dinding batu dengan celah pintu masuk di salah satu sudutnya. Sementara itu, Sanghyang Bedil dan Panyandaan merupakan bangunan seperti kedua bangunan sebelumnya, tetapi ditambah struktur batu di depan pintu masuk sehingga menghalangi orang untuk langsung masuk ke dalam bangunan. Situs Panyabungan Hayam merupakan hamparan dengan batu-batu datar dan menhir, sedangkan Sri Begawat Pohaci adalah tumpukan batu yang tidak beraturan dengan batu tegak di tengah ujung atas bangunan. Situs Adipati Panaekan adalah punden yang disusun melingkar dengan dua buah batu tegak di sebelah utara dan selatannya. Kedua batu tegak itu merupakan tambahan. Bangunan ini diasumsikan sebagai "makam" Adipati Panaekan, keturuan Raja Galuh yang diangkat sebagai Wedana di Tatar Sunda yang paling awal diangkat oleh Sultan Mataram dengan diberi 960 cacah. Situs Karangkamulyan diwarnai dengan mitosmitos yang dipercaya oleh masyarakat setempat, seperti nama Panyandaan yang dipercaya sebagai tempat Dewi Naganingrum (istri Raja Galuh) melahirkan anak laki-lakinya. Di tempat ini, Dewi menyandarkan diri selama 40 hari untuk memuluhkan kondisinya. Anak laki-laki tersebutlah yang bernama Ciung Wanara (Lubis, 2013, hal. 88 - 90).

Batu Pangcalikan dianggap sebagai tempat duduk Ratu Galuh, sedangkan Cikahuripan merupakan tempat pemandian yang mata airnya dari $\mathrm{Ci}$ Teguh dan $\mathrm{Ci}$ Rahayu. Situs Panyabungan Hayam merupakan lahan kosong yang dikelilingi pohon besar, tempat sabung ayam milik Ciung Wanara dengan ayam Hariang Banga. Temuan arca yang bercorak Hindu Buddha juga pernah didapatkan di situs Kerajaan Galuh, tepatnya di lokasi Batu Pangcalikan, yaitu dua buah arca Ganesa sederhana berukuran tinggi $46 \mathrm{~cm}$. Sikap duduknya bukan kurmasana (duduk bersila), melainkan ardhaparyangkasana (sikap duduk dengan cara melipat kaki ke atas sehingga lutut menempel di dada, sedangkan kaki yang lain dalam sikap bersila). Arca tersebut dibuat dengan permukaan yang kasar, tidak banyak ornamennya, tetapi sifat platisnya digarap dengan baik. Lapik (alas) arca bukan 
berupa padmasana (tempat sembahyang dan menaruh sesajian), melainkan bentuk lingkaran yang agak tidak beraturan (Munandar, 2010, hal. 79 - 81).

Pengelolaan Situs Karangkamulyan berada di bawah koordinasi Balai Pelestarian Cagar Budaya (BPCB) Banten. Upaya untuk menjadikan Situs Karangkamulyan menjadi tempat yang asri, menyenangkan, dan nyaman selalu dilakukan oleh pemerintah. Bahkan, saat ini di kawasan Situs Karangkamulyan sudah ada Museum Situs Karangkamulyan yang didirikan pada tahun 2014. Museum Situs Karangkamulyan awalnya merupakan ruang informasi dan ruang penyelamatan, yang pada tahun 1995 - 2013 diganti menjadi gedung penyelamatan cagar budaya $^{1}$. Dengan demikian, jumlah pengunjung ke situs tersebut meningkat. Selain itu, dengan kenyamanan tempat, Situs Karangkamulyan dapat dijadikan sebagai sumber/media belajar bagi siswa sekolah dari jenjang sekolah dasar hingga perguruan tinggi.

Media dibagi menjadi lima, dengan penjelasan sebagai berikut: (1) media visual, yaitu media yang dapat ditangkap dengan indra penglihatan (macamnya media gambar diam dan grafis; media papan; media dengan proyeksi, seperti filmstrips, slide, transparansi, dan mikrofilm), (2) media audio, yaitu media yang didengar (yang termasuk jenis media ini adalah cassete tape recorder dan radio), (3) media audio visual, yaitu media yang tidak hanya dapat dipandang atau diamati, tetapi juga dapat didengar (jenis media ini di antaranya televisi dan video kaset), (4)

1 Irma, 22 tahun, juru pelihara Museum Karangkamulyan, 15 Desember 2016. benda asli dan orang (yang termasuk jenis ini adalah spesimen, diorama, moleckup, laboratorium di luar sekolah, dan museum), dan (5) lingkungan (Suryani \& Leo, 2012, hal. 141 - 143). Sebagai sebuah media, Situs Karangkamulyan merupakan media benda asli dan lingkungan.

Kegiatan pengajaran yang dinilai baik ialah pengajaran yang melibatkan siswa dalam proses belajar mengajar, yaitu siswa perlu diberi kesempatan dan kemudahan untuk menemukan sendiri pengetahuannya. Agar siswa dapat lebih aktif dalam menggali dan menganalisis peristiwa sejarah, guru hendaknya cermat dalam memilih dan menggunakan metode mengajar, terutama metode mengajar yang mempunyai kadar interaktif cukup tinggi.

Metode pembelajaran sejarah antara lain adalah ceramah, diskusi, pemecahan masalah, demonstrasi, sosiodrama, eksperimen, tugas, dan resitasi, serta karyawisata atau field trip (ekskursi). Metode ceramah adalah penuturan bahan pelajaran secara lisan. Metode diskusi adalah penyajian pelajaran dengan mengemukakan suatu permasalahan dan peserta didik diharapkan untuk membahas dan memecahkannya. Metode problem solving (pemecahan masalah) merupakan suatu metode berpikir sebab dalam metode pemecahan masalah dapat digunakan metode-metode lainnya untuk mencari data agar dapat ditarik simpulan. Metode demonstrasi adalah cara penyajian bahan pelajaran dengan memperagakan atau mempertunjukkan kepada siswa suatu proses, situasi, atau benda tertentu yang sedang dipelajari, baik sebenarnya ataupun tiruan yang disertai dengan penjelasan. Metode sosiodrama pada dasarnya mendemonstrasikan tingkah laku dalam hubungannya dengan kehidupan sosial 
ataupun budaya. Metode eksperimen (percobaan) merupakan cara penyajian pelajaran, yaitu siswa melakukan percobaan dengan mengalami dan membuktikan sendiri suatu yang dipelajari mereka. Metode tugas dan resitasi merupakan metode penyajian bahan, yaitu guru memberikan tugas tertentu agar siswa melakukan kegiatan belajar. Metode karyawisata berarti kunjungan ke luar kelas dalam rangka belajar (Suryani \& Leo, 2012, hal. 55 - 65).

Dalam dunia pendidikan, terutama dalam pembelajaran sejarah, situs-situs, seperti Situs Karangkamulyan dapat dimanfaatkan sebagai sumber belajar siswa. Sumber-sumber sejarah merupakan alat-alat (means, tools). Sebuah sumber sejarah dapat berupa suatu produk dari kegiatan-kegiatan manusia yang memuat informasi tentang kehidupan manusia meskipun produk ini mula-mula tidak dimaksudkan untuk memberikan informasi pada generasi kemudian. Akan tetapi, dapat juga sumber itu berupa sesuatu yang benar-benar memberikan informasi tentang kegiatan-kegiatan manusia dan secara eksplisit sengaja direncanakan untuk itu (Sjamsudin, 2012). Situs Karangkamulyan merupakan produk dari kegiatan manusia yang memuat informasi kehidupan manusia, seperti Makam Adipati Panaekan. Adipati Panaekan adalah seorang adipati yang ditugaskan oleh Sultan Mataram untuk memimpin Galuh dan ia tewas pada tahun 1625 akibat perselisihan dengan adik iparnya, Dipati Kertabumi.

Sementara itu, sumber-sumber sejarah juga dapat dibagi dalam beberapa, yaitu sumber yang tidak sengaja (unpremeditated) dan yang disengaja (intentional). Sumber yang tidak sengaja antara lain artefak, surat perjanjian dagang, ijazah, dan sesuatu yang mempunyai nilai pada masanya. Sumber yang disengaja, antara lain surat wasiat, daftar silsilah keluarga, dan prasasti (Widja, 1991, hal. 20). Apabila dilihat dari kategori kesengajaan dan ketidaksengajaan, Situs Karangkamulyan termasuk dalam kategori sumber yang tidak disengaja. Tinggalan arkeologis yang ada di Situs Karangkamulyan tidak sengaja dibuat untuk menginformasikannya pada generasi yang akan datang.

Association of Educational Communication and Technology (AECT) mengartikan sumber belajar sebagai sesuatu yang dapat digunakan untuk memfasilitasi kegiatan belajar. Sumber ini diklasifikasikan menjadi dua, yaitu resources by design (sumber belajar yang dirancang) dan resources by utilization (sumber belajar yang dimanfaatkan). Sumber belajar yang dirancang adalah sumber belajar yang sengaja direncanakan untuk keperluan pembelajaran, misalnya buku paket, modul, dan lembar kerja siswa (LKS). Sumber belajar yang dimanfaatkan adalah segala sesuatu yang sudah tergelar di sekitar kita dan dapat dimanfaatkan untuk keperluan belajar, contohnya bank, pengadilan, pasar, museum, kebun binatang, dan lingkungan. Semuanya itu tidak dirancang untuk pembelajaran karena memang sudah tersedia, tinggal dimanfaatkan (Anitah, 2014, hal. 5). Demikian juga dengan Situs Karangkamulyan, yang merupakan sumber yang sudah tersedia dan tinggal dimanfaatkan.

Memang, selama ini, pemanfaatan situs-situs di Ciamis, terutama Situs Karangkamulyan untuk kepentingan pendidikan, khususnya pembelajaran 
sejarah yang diselenggarakan di sekolah dan perguruan tinggi, belum maksimal. Bahkan, sebagian besar pembelajaran hanya sampai pada tingkat hafalan sehingga peserta didik kurang mampu memahami dan menghubungkan apa yang mereka pelajari dengan kehidupan nyata.

Kondisi ini tentu saja memberikan pandangan negatif bagi siswa bahwa sekolah hanya menyajikan hal-hal yang bersifat teoretis saja, ditambah lagi dengan lemahnya kemampuan guru dalam menghubungkan apa yang mereka pelajari dengan lingkungan sekitar dan kehidupan yang nyata.

Pengintegrasian pembelajaran dengan lingkungan (Situs Karangkamulyan) ini dapat membantu siswa untuk memahami materi yang disampaikan di kelas. Salah satu model yang dapat diterapkan dan berkaitan dengan upaya pemanfaatan peninggalan sejarah adalah model pembelajaran kontekstual atau CTL (Contextual Teaching and Learning). Pembelajaran CTL merupakan konsep pembelajaran yang menekankan pada keterkaitan antara materi pembelajaran dengan dunia kehidupan nyata sehingga siswa mampu menghubungkan dan menerapkan kompetensi hasil belajar dalam kehidupan sehari-hari. Dalam pembelajaran kontekstual, tugas guru adalah memberikan kemudahan belajar kepada siswa, dengan menyediakan berbagai sarana dan sumber belajar yang memadai. Kegiatan siswa dalam pembelajaran kontekstual diarahkan agar siswa melakukan sharing untuk memperoleh masukan dan tanggapan dari orang lain. Situasi belajar dibuat menyenangkan dan tidak membosankan sehingga siswa belajar dengan gairah dan minat yang tinggi (Ghufron, 2009, hal.
19). Pemanfaatan Situs Karangkamulyan untuk pembelajaran sejarah adalah dengan menggunakan metode ekskursi/ karyawisata. Peserta didik/siswa diajak ke luar kelas (Situs Karangkamulyan) dalam rangka belajar. Pokok bahasan yang berkaitan dengan Situs Karangkamulyan untuk siswa menengah atas adalah tentang Prinsip-Prinsip Dasar Penelitian Sejarah, Kerajaan Hindu-Buddha, dan Wujud Akulturasi Hindu-Buddha, sedangkan untuk mahasiswa dapat dikaitkan dengan mata kuliah Sejarah Indonesia Masa Hindu-Buddha, Sejarah Lokal, dan Pengantar Ilmu Sejarah.

Pelajaran sejarah hendaknya dimulai dari fakta-fakta sejarah yang dekat dengan lingkungan tempat tinggal siswa, baru kemudian pada fakta-fakta yang jauh dari tempat tinggalnya. Satu pembelajaran, di dalamnya, dapat terintegrasi dengan materi yang lain. Sebagai bahan acuan belajar, dapat dipergunakan berbagai sumber sejarah lokal yang ada di lingkungan sekitarnya sehingga siswa aktif mencari sumber yang diperlukan. Di sini siswa terlatih berdiskusi dengan teman dan terlatih menjalin komunikasi dengan orang lain atau masyarakat sekitar, sedangkan guru lebih berperan sebagai fasilitator.

Beberapa hal yang harus menjadi pertimbangan dalam pemilihan media dan/atau sumber belajar adalah kesesuaian dengan tujuan pembelajaran yang ingin dicapai, karakteristik siswa, keadaan latar atau lingkungan, dan kemudahan jangkauan (Sadiman, Rahardjo, Haryono, \& Rahardjito, 2012, hal. 84). Sebagai sebuah sumber belajar, Situs Karangkamulyan tentunya juga harus memenuhi dasar-dasar pertimbangan tersebut. 
Situs Karangkamulyan dapat memenuhi standar kesesuaian dengan tujuan pembelajaran apabila materi yang dibahas pada tingkat sekolah menengah atas adalah tentang PrinsipPrinsip Dasar Penelitian Sejarah, Kerajaan Hindu-Buddha, dan Wujud Akulturasi Hindu-Buddha. Misalnya, tujuan pembelajaran untuk materi Prinsip-Prinsip Dasar Penelitian Sejarah adalah menjelaskan sumber, data, dan fakta sejarah; menjelaskan perbedaan artefak, fakta mental, dan fakta sosial; dan mengidentifikasi jejak-jejak sejarah (Tuti, 2014, hal. 30).

Kesesuaian Situs Karangkamulyan dengan karakteristik siswa sekolah menengah atas dan perguruan tinggi tidak diragukan lagi karena karakteristik anak pada usia tersebut senang dengan hal yang sifatnya santai. Di Situs Karangkamulyan siswa dapat merasakan suasana santai dalam belajar sehingga tidak membosankan.

Keadaan latar atau lingkungan Situs Karangkamulyan untuk belajar cukup nyaman, hanya perlu ditambah sarana untuk berkumpul siswa yang tidak terkena panas dan hujan.

Lokasi Situs Karangkamulyan mudah dijangkau karena terletak di sisi jalan raya utama provinsi dan sarana transportasi ke tempat tersebut juga banyak. Hal ini menjadikan Situs Karangkamulyan tepat dipilih sebagai sumber belajar bagi siswa.

Meskipun begitu, Situs Karangkamulyan minim dimanfaatkan sebagai sumber belajar siswa. Hal ini disebabkan terkendala izin dari pihak kepala sekolah dan biaya tambahan yang dibebankan pada siswa. Hal lain yang menyebabkan kurangnya pemanfaatan Situs Karangkamulyan adalah publikasi yang tidak didistribusikan ke sekolahsekolah sehingga informasi tentang tinggalan dan sarana apa saja yang ada di Situs Karangkamulyan tidak sampai ke pihak guru dan siswa.

Di sisi lain, guru sejarah perlu memahami keberadaan Situs Karangkamulyan sebagai sumber belajar. Walaupun di dalam buku ajar materi tersebut tidak dibahas secara terperinci, Situs Karangkamulyan merupakan situs peninggalan Kerajaan Galuh, yaitu kerajaan yang pernah ada di tanah Priangan Timur. Hal ini bertujuan agar siswa dapat menghargai peninggalan sejarah. Selain itu, metode studi wisata/ ekskursi ke Situs Karangkamulyan sangat menarik dan memotivasi siswa serta menambah wawasan.

Situs-situs memiliki potensi untuk membantu siswa menjadi mengerti maknanya, aktif dan kritis terhadap "isi" dari masa lalu dan penerapannya hingga saat ini. Peringatan dan situs warisan menawarkan banyak peluang bagi para guru dan siswa untuk terlibat dengan arti penting sejarah dan untuk mengembangkan alat intelektual agar lebih memahami bagaimana hubungan masa lalu dan masa kini. Model pembelajaran ini memiliki manfaat yang cukup besar dalam menginformasikan bagaimana kaum muda belajar untuk berpikir secara historis, ada lebih banyak pekerjaan dibutuhkan untuk mengembangkan pendekatan ini, melalui berpikir tentang makna sejarah yang tidak hanya mencerminkan tampilan disiplin subjek tetapi juga dimensi sosial dan budaya. 


\section{SIMPULAN DAN SARAN}

\section{Simpulan}

Situs Karangkamulyan dapat dimanfaatkan sebagai sumber belajar siswa. Sebagai sebuah sumber belajar, Situs Karangkamulyan sudah memenuhi kriteria sebagai sumber belajar yang dapat dipilih. Pemanfaatan Situs Karangkamulyan untuk kepentingan pendidikan terutama dalam pembelajaran sejarah dilaksanakan melalui integrasi materi yang diajarkan dalam mata pelajaran sejarah di tingkat sekolah menengah atas dengan pokok bahasan Prinsip-Prinsip Dasar Penelitian Sejarah, Kerajaan Hindu-Buddha, dan Wujud Akulturasi Hindu-Buddha. Bagi kalangan mahasiswa, Situs Karangkamulyan dapat dikaitkan dengan mata kuliah Sejarah Indonesia Masa Hindu-Buddha, Sejarah Lokal, dan Pengantar Ilmu Sejarah. Metode yang dapat digunakan di antaranya ekskursi/ studi karyawisata.

Kendala yang dihadapi adalah waktu jam pelajaran yang terbatas, izin dari kepala sekolah, dan biaya tambahan yang dikeluarkan siswa/mahasiswa. Kendala lain adalah publikasi tentang Situs Karangkamulyan yang tidak terdistribusikan ke sekolah-sekolah dan perguruan tinggi.

\section{Saran}

Bagi guru, untuk meningkatkan kualitas pembelajaran dan menumbuhkan minat siswa dalam belajar sejarah, seyogianya guru memanfaatkan sumber belajar yang dekat dengan lingkungan sekolah. Untuk meningkatkan sikap profesional guru, kepala sekolah perlu mengintensifkan pembinaan dan supervisi kepada guru berkaitan dengan persiapan mengajar ataupun pelaksanaan pembelajaran.

Bagi BPCB Banten, perlu dibangunnya tempat yang nyaman untuk berkumpul siswa pada saat hujan, yang dilengkapi dengan sarana untuk presentasi/ in focus.

Bagipengelola Situs Karangkamulyan, untuk meningkatkan dan menarik pengunjung terutama dari kalangan pelajar, perlu dikembangkan kerja sama dengan institusi pendidikan (sekolah) dan guru, melalui perintisan program kunjungan ke Situs Karangkamulyan dengan berbagai kemudahan. Agar pengunjung memperoleh gambaran yang utuh tentang situs, pantas dipertimbangkan untuk menyiapkan brosur (buku) praktis dengan harga yang terjangkau, khususnya bagi pelajar. Hal ini juga dapat dijadikan sarana publikasi.

\section{DAFTAR PUSTAKA}

Agung, L., \& Wahyuni, S. (2013). Perencanaan Pembelajaran Sejarah. Yogyakarta: Ombak.

Anitah, S. (2014). Media Pembelajaran. Surakarta: UNS Press.

Furchan, A. (2011). Pengantar Penelitian Dalam Pendidikan. Yogyakarta: Pustaka Pelajar.

Ghufron. (2009). Pelajaran Islamisasi Melalui Metode Resitasi Dengan Objek "Menara Kudus". Tesis Pascasarjana, Surakarta: Universitas Sebelas Maret.

Haris, A., \& Budiana D. (2013). Cerita Rakyat Ciung Wanara. Ciamis: Galuh Nurani.

Kochhar, S. (2008). Pembelajaran Sejarah. Jakarta: Grasindo. 
Lubis, N. H. (2013). Sejarah Kerajaan Sunda. Bandung: Yayasan MSI.

Munandar, A. A. (2010). Tatar Sunda Masa Silam. Jakarta: Wedatama Widya Sastra.

Sadiman, A., Rahardjo, R., Haryono, A., \& Rahardjito. (2012). Media Pendidikan: Pengertian, Pengembangan, dan Pemanfaatannya. Depok: Raja Grafindo Persada.

Saptono, N. (1999). Permukiman di Sekitar Kabuyutan Karangkamulyan. Jurnal Penelitian Balai Arkeologi Bandung Nomor 5/Maret, 36 - 46.

Saptono, N. (2002). Karangkamulyan a Historical Event And an Archaeological Site. Jakarta: Proyek Pengembangan Kebijakan Kebudayaan, Kementerian Kebudayaan dan Pariwisata.

Sharer, R. J., \& Ashmore, W. (2003). Archaeology: Discovering Our Past. New York: The Mc Graw-Hill Companies.

Sjamsudin, H. (2012). Metodologi Sejarah. Yogyakarta: Ombak.

Suryani, N., \& Leo, A. (2012). Strategi Belajar Mengajar. Yogyakarta: Ombak.

Tuti. (2014). Rencana Pelaksanaan Pembelajaran Sejarah. Ciamis.

Widja, I. G. (1991). Sejarah Lokal: Suatu Perspektif Dalam Pengajaran Sejarah. Bandung: Angkasa. 